\title{
RESEARCH PUBLICATIONS SERIES
}

ISSN 01437984

\section{OF THE WELLCOME UNIT FOR THE HISTORY OF MEDICINE}

Started in 1979, the series is intended to make available at low cost bibliographical, documentary and research aids in fields relating to the history of health and medicine.

I. The Preservation of Medical and Public Health Records. iv +52pp. $£ 1 \cdot 00 / \$ 2 \cdot 00$.

II. Charles Webster, Utopian Planning and the Puritan Revolution: Gabriel Plattes, Samuel Hartlib and Macaria. vi +89 pp. $£ 2 \cdot 00 / \$ 3 \cdot 00$. illus.

III. Margaret Pelling, Handlist of Records of the Society of Medical Officers of Health. iv + 23pp. $£ 1 \cdot 00 / \$ 2 \cdot 00$.

IV. Ludmilla Jordanova (ed.), Medical Records Newsletter. 52pp. $£ 1 \cdot 50 / \$ 2 \cdot 50$.

V. Paul Weindling, From Bacteriology to Social Hygiene: The Papers of Martin Hahn (1865-1934). viii +22pp. £2·50/\$4.00. illus.

VI. W.R. LeFanu, British Periodicals of Medicine, a Chronological List 16401899 (Revised edition). xiv + 70pp. £3.00/\$5.00.

VII.Margaret Pelling, Handlist of Public Health Records. 35pp. £2.00/\$3.00.

Obtainable from the Wellcome Unit for the History of Medicine, University of Oxford, 45-47 Banbury Road, Oxford OX2 6PE, UK.

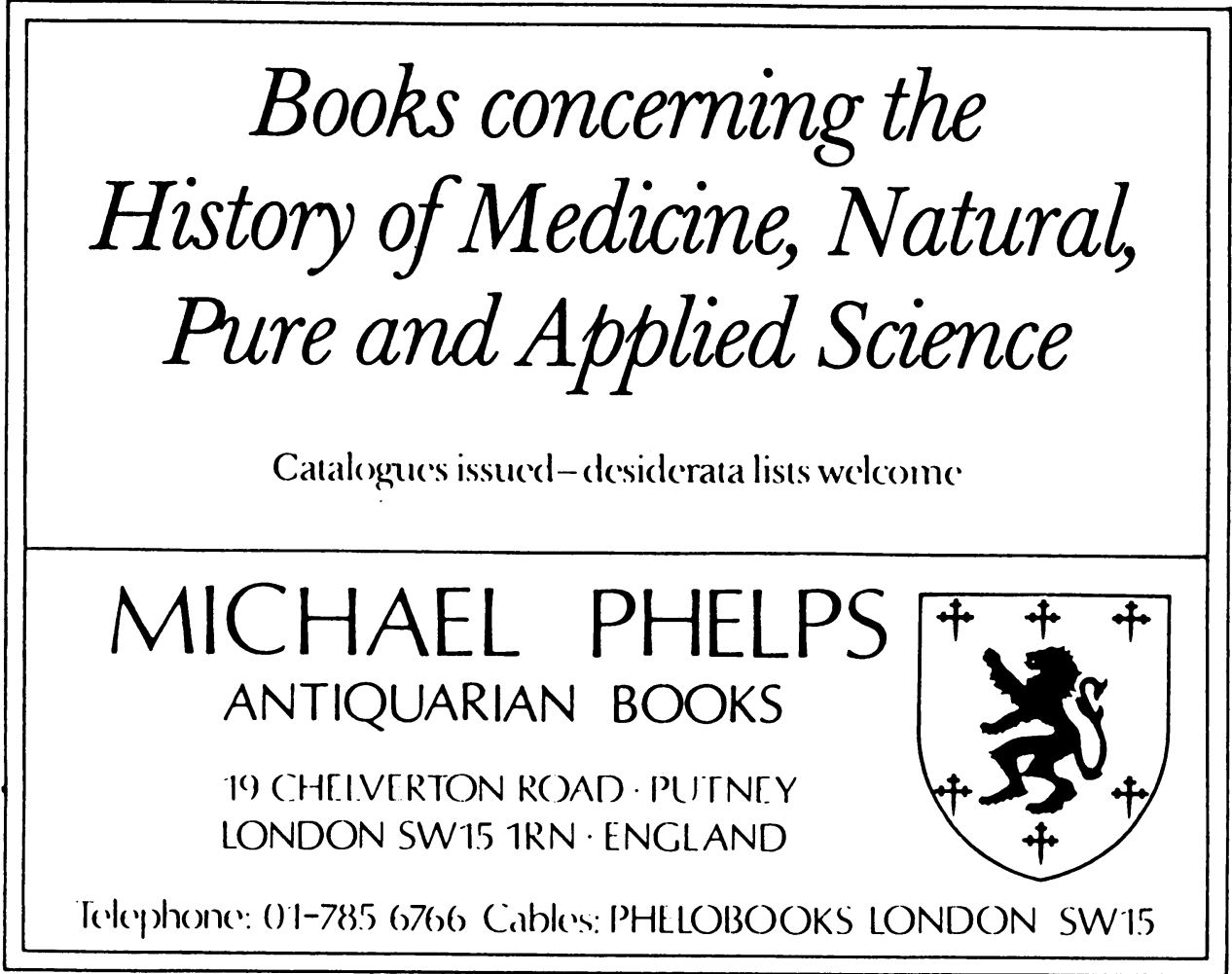




\section{History of Science}

the only review of literature and research in the history' of science, medicine and technology in its intellectual and social context

\section{2-1985}

\section{A special post-free offer to new subscribers valid until 31 December 1986}

\section{Volumes 1-23 hardbound, US \$475/£250}

From Science History Publications Ltd, Halfpenny Furze, Mill Lane, Chalfont St Giles, Bucks HP8 4NR, England.

History of Science is published quarterly in issues of about 112 pages.

Volume 24 (1986) will include

J. A. BENNETT The Mechanics' Philosophy and the Mechanical Philosophy

SUSAN LEIGH STAR Triangulating Clinical and Basic Research: British Localizationists, 1870-1906

MICHAEL HUNTER AND PAUL B. WOOD Towards Solomon's House: Rival Strategies for Reforming the Early Royal Society

BRUCE EASTWOOD Medieval Science Illustrated

ROBERT ASCHER AND MARCIA ASCHER Ethnomathematics

T. D. STOKES Reason in the Zeitgeist

M. M. SUAREZ AND W. LEMOINE From Internalism to Externalism: A Study of Academic Resistence to New Scientific Findings

DAVID R. OLDROYD Grid/Group Analysis for Historians of Science?

The Annual Subscription is US $\$ 81.00$ post-free in the Americas and Japan, $£ 40.50$ elsewhere $(\$ 42.00 / £ 19.50$ direct to private subscribers). Write to: Science History Publications Ltd, Halfpenny Furze, Mill Lane, Chalfont St Giles, Bucks HP8 4NR, England 


\section{MEDICAL BOOKS}

\section{Prints * Portraits}

\section{Old, Rare,}

\& OUT-OF-PRINT

\section{America's Largest Stock}

All items are fully catalogued and classified. American and European. dating from the 15th to the 20th centuries particularly classical and unusual works. with emphasis upon history, biography, and specialized medicine.

Lists issued in all fields of medicine.

We are eager to purchase small or large collections.

\section{ARGOSY BOOK STORES}

116 E. 59th St., N.Y., N.Y. 10022, PL.3-4455
F. E.

Whitehart

40 Priestfield Rd.

Forest Hill

London SE23 2RS

01-699 3225
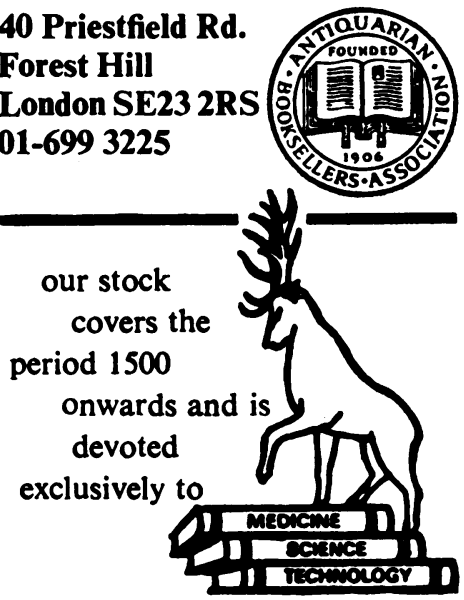

CATALOGUES ISSUED

Normal business hours or by appointment
Rare Books \& Manuscripts in the bistory of

Medicine \& the Sciences

BOUGHT · SOLD · APPRAISED

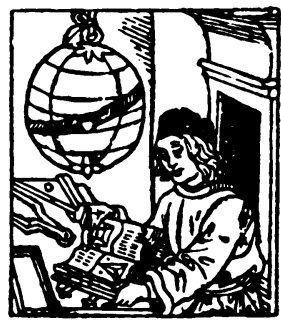

Send for our latest catalogue

Jeremy Norman \& Co., Inc.

$4+2$ POST STREET

SAN FRANCISCO, C.ALIFORNIA $9+102$

(415) $781-6402$

\section{Nigiel Qhillips $_{\text {RAREBOOKS }}$}

Antiquarian books in the history of medicine and the health sciences.

Please send for my catalogue.

\section{RADCLIFFE SQUARE}

PUTNEY HILL

LONDON SW15 6BL

ENGLAND

Tel: 01-7882664 